https://helda.helsinki.fi

\title{
The Cheshire Cat that is International Law
}

\section{Klabbers, Jan}

2020

Klabbers , J 2020 , ' The Cheshire Cat that is International Law ' , European Journal of International Law , vol. 31 , no. 1 , pp. 269-283 . https://doi.org/10.1093/ejil/chaa018

http://hdl.handle.net/10138/325580

https://doi.org/10.1093/ejil/chaa018

unspecified

Downloaded from Helda, University of Helsinki institutional repository.

This is an electronic reprint of the original article.

This reprint may differ from the original in pagination and typographic detail.

Please cite the original version. 
The Cheshire Cat that is International Law

Jan Klabbers ${ }^{1}$

I. Introduction

This issue of the European journal of International Law contains three wonderful, exemplary articles on, roughly, international law-making. Danae Azaria makes the careful argument that the International Law Commission (ILC) has become entrusted (and justifiably so, she suggests) with the task of authoritatively interpreting international law. Kristina Daugirdas demonstrates that customary international law cannot only be made by states, but also by international organizations, therewith throwing new light on a topic that has remained in the shadows for all too long perhaps. And Orfeas Chasapis Tassinis subtly and with sophistication argues that interpretation is not a process limited to written texts but, in the context of international law, also governs the formation and identification of customary international law. All three papers make valuable contributions to our understanding, and all three authors make a plausible case for their positions.

And yet, something does not quite seem right: there is a sense that the papers are barking up the wrong tree - are engaged in discussions that are no longer quite as central to international law as they may once have been. What is more (and this may be related), the three papers all seem to operate in a political vacuum, presupposing that the making of international law can be reduced to a technical exercise, informed at best by analytical-philosophical considerations but without any concern for political concepts such as legitimation, democracy, representation, or accountability. It is questionable whether such an approach can inform more "technical" questions (assuming this is a meaningful category to begin with), but with respect to the making of law - a quintessentially political affair - doctrine is at its best when it steps out of its own vacuum.

In what follows I will aim to sketch my concerns, thinking of law-making in terms of the exercise and reception of authority (section II) and the distribution of costs and benefits accompanying all legal decision-making and institution-building (section III), before commenting in somewhat greater detail on the papers by Azaria, Daugirdas and Chasapis Tassinis (section IV). Section V concludes.

\section{Global Governance: The Exercise and Reception of Authority}

From the early 1990s until the 2010s, the words "global governance" were on everyone's lips well, everyone with an interest in international affairs, that is. James Rosenau was among the first to observe that governance could be exercised without a duly appointed government. ${ }^{2}$ Craig Murphy suggested much the same in his excellent study of the role of international organizations

\footnotetext{
${ }^{1}$ University of Helsinki. jan.klabbers@helsinki.fi

2 J. Rosenau and E.-O. Czempiel (eds), Governance without Government: Order and Change in World Politics (1992).
} 
as the pivots around which telecommunications revolutions revolved, ${ }^{3}$ and it soon transpired that the concept could even inspire the establishment of a new journal, and a meaningful one at that. ${ }^{4}$ Global governance may have been someone's political project, a companion ideology to help justify and legitimize globalization, ${ }^{5}$ but it was also immediately recognized to be more than that both a mode of exercising authority and a perspective on the use of authority in international affairs. ${ }^{6}$ For, it became clear, authority was exercised in a wide variety of ways and by a wide variety of actors and, what is more, was increasingly exercised directly over a wide variety of subjects. The state, or so it seemed, was bypassed from all angles: no longer sole law-maker, no longer sole law-recipient. A new world order was in the making, or had possibly already arrived. ${ }^{7}$ None of this was exactly novel in the 1990s, except for the label "global governance". Once the ontological reality of international organizations had come to be accepted, after some hesitant beginnings ${ }^{8}$ following the ICJ's milestone opinion in Reparation for Injuries ${ }^{9}$ a lively debate broke out over the subjects of international law - a debate that continues to this day. ${ }^{10}$ Law-making, in turn, was mulled over from the 1950 s onwards, ${ }^{11}$ focusing on whether there could be memoranda of understanding and if so, whether these have legal effect, ${ }^{12}$ and this debate soon came to be accompanied by further debates involving clever new labels: not just "instant custom", ${ }^{13}$ but also, and more prominently still, "soft law". ${ }^{14}$ And at the other end concepts such as jus cogens and erga omnes obligations emerged, ${ }^{15}$ suggesting again - if from a different vantage point - that authority was exercised in different ways than had traditionally been the case, something later captured in the thought that international law was constitutionalizing. ${ }^{16}$ It was clear that lawmaking no longer solely followed the traditional route of sovereign states solemnly gathering, making sure their minds would meet, and laying down the results in the form of a legally binding agreement which, whatever its designation, would be a treaty. It was clear that authority came in

\footnotetext{
${ }^{3}$ C. Murphy, International Organization and Industrial Change: Global Governance since 1850 (1994).

${ }^{4}$ The journal Global Governance emerged from the circles around the Academic Council on the United Nations System (ACUNS), and was first published in 1995. Its first co-editor in chief was the same Craig Murphy.

${ }^{5}$ Friedman, 'Globalization', in D. Nugent and J. Vincent (eds), A Companion to the Anthropology of Politics (2004) 179.

${ }^{6}$ An authoritative collection is D. Avant, M. Finnemore and S. Sell (eds.), Who Governs the Globe? (2010).

${ }^{7}$ A.-M. Slaughter, A New World Order (2004).

${ }^{8}$ Oppenheim, 'Le caractère essential de la Société de Nations', (1919) 26 Revue Générale de Droit International Public, 234.

${ }^{9}$ Reparation for Injuries Suffered in the Service of the United Nations, advisory opinion [1949] ICJ Reports 174.

${ }^{10} \mathrm{~K}$. Parlett, The Individual in the International Legal System: Continuity and Change in International Law (2011); R. Uruena, No Citizens Here: Global Subjects and Participation in International Law (2012).

${ }^{11}$ Fawcett, 'The Legal Character of International Agreements' ((1953) 30 British Yearbook of International Law, 381.

${ }^{12}$ Aust, 'The Theory and Practice of Informal International Instruments' (1986) 35 International and Comparative Law Quarterly, 787; Klabbers, 'Governance by Academics: The Invention of Memoranda of Understanding' (2020) 80 Zeitschrift für ausländisches öffentliches Recht und Völkerrecht (forthcoming).

${ }^{13}$ Bin Cheng, "United Nations Resolutions on Outer Space: "Instant" International Customary Law?", reproduced in Bin Cheng (ed.), International Law: Teaching and Practice (1982) 237.

${ }^{14}$ The literature is voluminous: see e.g. Chinkin, 'The Challenge of Soft Law': Development and Change in International Law', (1989) 38 International and Comparative Law Quarterly, 850; Klabbers, 'The Redundancy of Soft Law', (1996) 65 Nordic Journal of International Law, 167.

${ }^{15}$ Weil, 'Towards Relative Normativity in International Law?', (1983) 77 American Journal of International Law, 413. ${ }^{16} \mathrm{~J}$. Klabbers, A. Peters and G. Ulfstein., The Constitutionalization of International Law (2009); Klabbers, 'International Constitutionalism', in R. Masterman and R. Schütze (eds), The Cambridge Companion to Comparative Constitutional Law (2019) 498.
} 
all sorts of manifestations, an "infinite variety"17 of all sorts of "twilight"18 instruments existing on the "legally subliminal level", ${ }^{19}$ and sometimes also proper treaties containing strong elements of "noncommitment in the commitment", as Glennon memorably referred to Article 5 NATO. ${ }^{20}$ In retrospect, possibly the most fundamental development was, paradoxically perhaps, widely discussed but rarely seen for what it was: the emergence of the individual as the direct recipient of international law. And perhaps this was so because the discipline of international law, or law generally, was wrongfooted by earlier diagnostics. It had been clear since the late 1920s that international law could have direct effect; the Permanent Court of International Justice (PCIJ) had said as much in its Courts of Danzig opinion, stipulating only that as a matter of international law, such depended on the intentions of states. If states so desire, their agreements might be directly effective in domestic legal orders. ${ }^{21}$ But the Courts of Danzig opinion still entailed that direct effect was, so to speak, rather indirect, mediated by states, and requiring implementation by states of more or less monist persuasion. Increasingly though, this seemed rather cumbersome and artificial, with business transactions taking place across boundaries, with human rights being promulgated, with international organizations producing norms aimed at affecting the individual (who else would international labour conventions or international health regulations be meant for?), and especially with the creation of the European Communities. These were clearly part of international law, in some respects, and equally clearly distinct from international law, as the European Court of Justice was quick to recognize. ${ }^{22}$ Hence, the contours of a new landscape became vaguely discernible by the mid-1950s, a landscape immortalized by Philip C. Jessup under the heading of "transnational law". ${ }^{23}$

Transnational law and global governance are different concepts, ${ }^{24}$ with different focal points and different points of emphasis, but both spring from the same core observation. They start from the position that the old, classic, nineteenth century system of international law, built around states, making law for states, affecting states and states only, through a handful of generally recognized types of legal source or instrument, no longer holds. This nineteenth century system culminated in the authoritative list of sources contained in article 38 of the Statute of the International Court of Justice (ICJ) and before it of the PCIJ. It lingers on like the smile of the Cheshire cat, longer after the cat itself has disappeared from view.

To be sure, traditional sources doctrine, exemplified by Article 38 ICJ Statute, is still heuristically useful, a fine starting point for a discussion on the way law is made in international society - that discussion has to start somewhere, after all. But it was probably never meant as an exhaustive list of how law could be made, and if it was intended to be exhaustive, then it was neither persuasive nor successful. As a starting point for a conversation, Article 38 is fine. As a description aiming

\footnotetext{
${ }^{17}$ Baxter, 'International Law in “Her Infinite Variety"', (1980) 29 International and Comparative Law Quarterly, 549.

${ }^{18}$ Schachter, 'The Twilight Existence of Nonbinding International Agreements', (1977) 71 American Journal of International Law, 296.

${ }^{19}$ S. Neff, Friends but No Allies (1990), 145-6.

${ }^{20}$ M. Glennon, Constitutional Diplomacy (1990) 214.

${ }^{21}$ Jurisdiction of the Courts of Danzig, advisory opinion, [1928] Publ. PCIJ, Series B, no. 15.

${ }^{22}$ Case 26/62, Van Gend and Loos v Netherlands Internal Revenue Administration, [1963] ECR 1.

${ }^{23}$ Ph.C. Jessup, Transnational Law (1956).

${ }^{24}$ N. Walker, Intimations of Global Law (2015).
} 
accurately to reflect the ways in which international law is made or where international law springs from, however, it is hopelessly inadequate, and there is something mildly alienating about attempting to squeeze all exercises of authority into three boxes: that of the treaty, that of custom, and that of the general principles of law.

The problem here is not solely one of descriptive accuracy, although it is that too. Without denying the possibility that, e.g., resolutions of the General Assembly may come to form the basis of a later treaty (think of the Genocide Convention) or come to pass into customary international law (as happened with quite a few of the rights first promulgated in the Universal Declaration ${ }^{25}$ ), it is nonetheless obvious that the normative output of international organizations, for instance, can only be squeezed into these boxes with great difficulty. It does an injustice to think of the WHO's International Health Regulations as if it were a treaty, and part of the injustice resides in the circumstance that a major player in their development was the WHO itself. It is even far more difficult to think of other instruments in terms of the recognized sources: surely, a handbook on visa processing produced by the International Organization for Migration aims to exercise and does in fact exercise great authority, but is neither treaty nor custom nor general principle. The loan agreements of the IMF; directives in European Union law; standards promulgated by the International Civil Aviation Organization, or decisions by the World Health Organization to declare a health pandemic - all of them can perhaps be squeezed into the boxes made available by Article 38 (as instruments derived from treaties, or reflecting some general practice or general principle or other), but none of them fits there comfortably. And even then, what to do with OSCE recommendations, with no treaty but an ostensibly "politically binding" document as their basis? Or the Basel Guidelines on Banking Supervision, neither emanating from a "proper" international organization nor based on a "proper" treaty, but widely expected to have real-life effects of great authority? Or the communiqués of the G20, to which much the same applies? Or the Accord on Fire and Building Safety in Bangladesh, involving companies (or brands, rather) and trade unions ? $^{26}$ It is clear that all these represent attempts at recording agreement and exercising authority on the international level, but the traditional vocabulary and the traditional conceptual apparatus with which international lawyers are equipped is insufficient for a proper understanding. Inventing new labels might help, but only if those labels themselves are sufficiently clear, and that has never been the case with labels such as "soft law". Instead, the label "soft law" likely made things worse, by suggesting a veneer of understanding where none was present, and in the process diluting the idea of law as something that can come in varying shades of bindingness and providing authorities with unlimited license to rule. ${ }^{27}$

But, as noted, there is more to it than merely descriptive accuracy. Legal rules, of whatever provenance, typically allocate costs and benefits, whether tangible or intangible. Whenever a new rule is enacted, someone benefits or profits, and this applies even to coordination rules, of which it is often said that contents are irrelevant as long as they coordinate. ${ }^{28} \mathrm{It}$ may be that for the

\footnotetext{
${ }^{25}$ Others have remained largely aspirational, including the right to paid holidays.

${ }^{26}$ Some of these are included in J. Klabbers (ed.), International Law Documents (2016).

${ }^{27}$ Klabbers, 'The Redundancy'.

${ }^{28}$ See e.g. S. Strange, The Retreat of the State: The Diffusion of Power in the World Economy (1996). On coordination rules, see the discussion in R. Hardin, David Hume: Moral and Political Theorist (2007) 86-91.
} 
individual motorist it is indeed irrelevant whether one should drive on the right hand side or the left hand side of the road, as long as everyone does the same. However, the car manufacturer who does not take note of a change in the rule will run the risk of losing a significant share of the market.

Likewise, legal decisions (and indeed authoritative decisions generally) tend to have distributive effects. When the WHO declares a health pandemic, those pharmaceutical companies whose vaccinations are marketable might make good money; those whose vaccinations are still in development lose out. A decision to admit Palestine or Kosovo as a full member to an international organization will not just be functionally helpful (although it may be that too), but will also endow Palestine or Kosovo with a certain measure of recognition, quite likely much to the chagrin of Israel or Serbia. These decisions, in other words, have consequences, whether one realizes it or not; someone will be better off (regardless of how "better off" is measured, or whether the benefit at stake is financial, or social, or anything else), and someone is likely to be worse off. Often such results may be unintended, and yet they may be deeply invasive. ${ }^{29}$ Moreover, institutions are established precisely for distributive purposes. ${ }^{30}$ There is a deeply felt need to achieve a certain amount of fairness (again: however precisely conceptualized) in the distribution of costs and benefits, so much that this cannot be left to individuals, not even to those with Herculean capabilities. There is, after all, always a chance that Hercules' nephew applies for something, or that his next door neighbour's interests are at stake - setting up an institution then helps to take some of the unfairness out of the decision-making process, even if it is likely to result in structural biases of a different kind. And there are additional reasons why decisions of administrators are typically subject to review; or why decisions of lower judges can be contested on appeal - all of this plays a role in fine-tuning the allocation of costs and benefits. And the same logic helps explain why it is pointless to appeal to the outcomes of a lottery (presuming the lottery itself took place properly), or the sort of decision-making football coaches have to make when deciding who gets to play in which position in which match. ${ }^{31}$

\section{Global Governance: On Winners and Losers}

When international law was still thought to affect only states, without immediately affecting anyone else, none of this was considered very problematic. The free jostling of states would create an outcome, and it was obvious that the stronger states were expected to derive more benefits from the system than the weaker states. The invisible hand might keep the world spinning with some efficiency, but does little to guarantee fairness - something, incidentally, that Adam Smith

\footnotetext{
${ }^{29}$ See further Klabbers, 'Rules, Institutions, and Decisions: Taking Distribution Seriously', in G. Hellman and J. Steffek (eds), Essays on Praxis (working title, forthcoming).

30 J. Elster, Local Justice: How Institutions Allocate Scarce Goods and Necessary Burdens (1992); S. Miller, The Moral Foundations of Social Institutions (2010).

${ }^{31}$ Fuller conceptualized these as "polycentric tasks": see Fuller, 'The Forms and Limits of Adjudication' as reproduced in K. Winston (ed), The Principles of Social Order: Selected Essays of Lon L. Fuller, rev. edn. (2001) 101, 126.
} 
was all too aware of and tried to mitigate on the micro-level. ${ }^{32}$ In this classic system, political authority was deemed to be unproblematic, and it was deemed unproblematic precisely because the system was geared only towards states who, moreover, being sovereign and all that, would be perfectly at liberty to circumvent any unpleasant future obligations. Reality was considerably more resilient, as many in particular in the global south experienced, but the theory was neat: states would enter into obligations at their pleasure, upon approval by domestic audiences (the king, the politbureau, the parliament) or, just as likely, not at all. Either way, in terms of political obligation, in terms of political philosophy, the system was almost a closed circle: there was no strict need for domestic approval, as no domestic interests would be affected. ${ }^{33}$ Quod erat demonstrandum. The model was, quite obviously, untenable from the start, precisely because the state is an artificial person which, in an important sense, has no interests of its own. Governments (or rather, their members) may have interests, in that they may wish to be re-elected; companies (or rather, their owners) have interests, in that they may wish to make a profit; individuals may have an interest, in that they may wish to remain free from torture, earn a decent living, and see their holiday postcards delivered. But states are abstractions, to which of course abstract interests can be ascribed (survival, especially, or the rather hopelessly self-referential raison d'état), but whose own decisions and laws come to affect individuals - always and by definition. And when they make international law or apply international law, those interests of individuals will be affected, and that applies even to such inter-state activities as armed conflict. To say that war between states $A$ and $B$ is war between states $A$ and $B$ only on some inter-state level and does not, being international, affect the citizens of $A$ and $B$ is quite obviously nonsensical, and much the same applies on a different level of banality to, say, the activities of the Universal Postal Union (UPU). UPU may be an organization comprising 192 states, but it is clear that postcards and letters and packages are usually sent by individuals and companies rather than states - the idea that the UPU would merely apply on the inter-state level was always a fiction. Nothing could demonstrate this more plausibly than the US withdrawal from UPU announced in 2018 - and revoked in late 2019, after postal rates for US companies had been adjusted at an Extraordinary Congress, to the benefit of those US companies. ${ }^{34}$

In a world largely made up of liberal ideals, several basic assumptions vie for prominence, and perhaps the most basic of those is that people should be free to determine their own political and social futures. This is not universally guaranteed, with many states being democratic in name only, and quite a few not even that, but political autonomy is widely regarded as a basic component of political and social life, and it is only the autonomous individual who can bear responsibility for his or her actions. There is much debate about this at the margins and on points of detail, but the core proposition would seem to be universally embraced: the social and political ideal is that of men and women who are free to determine their own trajectories in life. And to this end, in many democracies, parliaments were established (often after intense political battle, as the powers that

\footnotetext{
${ }^{32}$ His more familiar work was accompanied by work in moral philosophy, in the form of A. Smith, The Theory of Moral Sentiments (2009 [1759]). For intelligent discussion, see R. Hanley, Adam Smith and the Character of Virtue (2009).

${ }^{33}$ This effectively describes the UK approach to international law, come to think of it.

${ }^{34}$ http://news.upu.int/no_cache/nd/upu-head-meets-with-us-president-following-geneva-agreement-onremuneration-rates/ (visited 31 October 2019).
} 
be typically want to remain in power); those parliaments would fight for their powers to be increased (until party politics made partisan positions more important) and the right to vote in a number of states steadily extended. ${ }^{35}$

But this created a legitimacy deficit for international law. If domestic law would increasingly draw on having somehow been discussed and decided on by domestic constituencies, the same logic did not apply to international law. Democratic control over foreign policy was rare to begin with, and often deemed merely obstructive: domestic parliamentarians were considered ignorant of the finer details of geopolitics and national interests, and would interfere with the conclusion of highlevel deals which could be vital to the state. ${ }^{36}$ As long as international law could be presented as merely affecting states in their relations with each other, this was not considered to be too much of a problem; but when it became clear that international law started directly to affect the rights and obligations, the costs and benefits, of individuals, the question of its political justification inevitably arose. And international law was lost for words; it had no response - and still has no response - to those who complain about its absence of democratic pedigree. Decisions directly affecting your material interests are taken by governors you have not elected or helped to appoint, by means of instruments you have no influence over nor even, often enough, cognizance of, and often through institutions that are far removed from your daily experience - no wonder people are a little upset.

\section{Azaria, Daugirdas, Chasapis Tassinis}

People may be (and are) upset, but the answer is not to be found in voting populist leaders into office, and the answer is not to be found in further technocracy either. Proposals by international bodies to fight populism by adopting resolutions against populism may provide Monty Python's heirs with some material for sketches, but are unlikely to have any real effects - and are therewith as depressing as what causes them, or perhaps even more so.

More to the point perhaps, neither is the answer to be found in fine-tuning sources doctrine, stretching our familiar boxes just a little to fit in additional instruments, or repackaging or rebranding the boxes of treaty, custom, and general principles. It is on this point that the excellent articles, elsewhere in this issue, by Danae Azaria, Kristina Daugirdas and Orfeas Chasapis Tassinis, need to be scrutinized.

Sources doctrine has always retained an air of mystery, despite having been around for well over a century (treaty and custom, after all, were discussed long before Article 38 saw the light). And yet, the important questions have always remained open, throughout the centuries: we still don't know what a treaty is, we still don't know what custom is, and we still don't know what a general principle is, despite attempts to conceptualize and systematize. ${ }^{37}$ There are moments when we think we know, when matters seem relatively clear; but these moments tend to be fleeting. We

\footnotetext{
${ }^{35}$ See, e.g., A.R. Myers, Parliaments and Estates in Europe to 1789 (1975).

${ }^{36}$ A typical statement from the early twentieth century (in Dutch) is A. Struycken, Het bestuur der buitenlandsche betrekkingen: een staatsrechtelijk en politiek vraagstuk (1918).

37 J. Klabbers, The Concept of Treaty in International Law (1996); A. d'Amato, The Concept of Custom in International Law (1971); Bin Cheng, General Principles of Law as Applied by International Courts and Tribunals (2006 [1953]).
} 
thought we knew what a treaty was when in 1950 Hersch Lauterpacht offered a definition, for purposes of the future Vienna Convention. As it turned out though, this very definition, by defining the treaty an instrument intended to create legal rights and obligations, opened the door for instruments intended to create rights and obligations that would be non-legal. After all, if it takes an intention to create a legal instrument, then it may also be possible to intend not to create a legal instrument. ${ }^{38}$ And we thought we knew what custom was when the ICJ presented a sensible conceptualization in North Sea Continental Shelf, ${ }^{39}$ emphasizing that what matters was that putative rules must be of a "norm-creating character". This turned out to be difficult with respect to rules that were normatively desirable but riddled with exceptions or whose application typically involves "balancing", in particular human rights norms - these might be "norm-creating" in an abstract sense, but less so on the ground. And because it is difficult to think of human rights in terms of classic custom, the suggestion arose that if some practices did not meet the standards of custom, perhaps they could still be seen as general principles, turning the latter into "custom lite". ${ }^{40}$

From these fundamental anxieties followed a number of further anxieties, especially with respect to custom. The ICJ in Nicaragua was confronted with the question whether state practice consists of action on the ground or in the drawing room, and opted for the latter. Normatively this was understandable, and probably the right thing to do, but it did mean that customary law was no longer, well, based on actual practice. And other fundamental questions have never been answered, indeed have rarely even been asked: what, e.g., is the status of non-practice? Here, Chasapis Tassinis has an important point: custom demands interpretation, in all its stages, and that includes the interpretation (call it "framing", if you will) of what counts as relevant practice for the formation of custom. Differently put, custom works on a curious binary basis, with practice divided into two groups: either relevant for the formation of a rule, or beside the point. But this ignores that practice itself is a fuzzy concept for any philosophy of action, mostly viewing only positive actions as relevant. Yet, every day Russia does not invade Finland may just as well be construed as contribution to the prohibition of aggression. And why count every day as a single instance? Perhaps the relevant unit should be the hour: every day Russia does not invade Finland counts as 24 bricks for the customary prohibition of aggression. The point is not to ridicule sources doctrine; the point is, instead, to emphasize that it has always been uncertain, and will most likely always remain uncertain.

Partly this is caused by having to adapt over time. Sources need to be somewhat stable, generating as they do legal rights and obligations, but need also to be flexible enough to accommodate change. There can be a lot at stake here: being able to point to a recognized rule of international law in order to justify your behavior provides a strong argument, stronger than doing the same thing without the support of a recognized rule. Hence, sources doctrine is forever bound

\footnotetext{
${ }^{38}$ For discussion, see Klabbers, 'Governance by Academics'.

${ }^{39}$ North Sea Continental Shelf (Germany/Denmark, Germany/The Netherlands), [1969] ICJ Rep. 3, para. 72.

${ }^{40}$ Simma and Alston, 'The Sources of Human Rights Law: Custom, Jus Cogens and General Principles', (1988) 12 Australian Yearbook of International Law, 82.
} 
to remain somewhat mysterious: for any mystery that will be unraveled, a new one will present itself, or, just as likely, the old one will return in a new guise.

This is not necessarily a bad thing. The twin demands of change and stability conspire to view sources doctrine as a platform for much-needed political debate, and as long as it does not lapse into telling agents that actually, they have been under obligation to act differently for a long time without realizing it, the constant attention for sources doctrine can offer and streamline political breathing space. On such a view, sources are not just about taming politics, but also about facilitating politics - even though this requires considerable judgment as to when to tame, and when to facilitate.

It is precisely with a view to the moment of choice (when to tame politics, and when to facilitate politics) that sources doctrine needs to be constantly and vigilantly undertaken, and with that in mind, the contributions by Chapasis Tassinis, Azaria and Daugirdas are to be welcomed. But the context should also make clear that sources doctrine is all the better and more convincing when informed by its political background and this, one senses, is not overwhelmingly present in their respective contributions.

Azaria compellingly argues that instead of making international law, the International Law Commission has become predominantly an interpreter of existing international law, and the underlying idea would seem to be that it is a good thing to have an interpretive organ of such authority available. Azaria's diagnostic is persuasive; her normative claim however somewhat less so, for surely, an ILC with this kind of authority comes close to being a legislator, without there being the intermediary step of the diplomatic conference to reconsider the work of the ILC. Pragmatically, there is much to be said for not submitting articles on state responsibility, or most other topics for that matter, to a diplomatic conference; but it does mean that power remains concentrated in the hands of the ILC - an organ of fairly little democratic pedigree, at best tapping into its professional expertise for legitimation of its practices.

Moreover, one has to wonder whether it displays the characteristics one may hope for in a twenty-first century legislator, such as representativeness. On this point, the ILC will be found seriously wanting. Its members may "run for office" in a colloquial sense, but this consists mostly of campaigning capital cities and proposing vote trades: you vote for me, l'll make sure we'll vote for your candidate judge to the International Criminal Court, or will support your candidacy for a seat on the Peacebuilding Commission. ${ }^{41}$ Much the same is true for other bodies, but at least with other bodies there is either also a strong component of expertise involved over and above politics (as with the ICJ), or else they lack the sense of a-political authority Azaria wishes to ascribe to the ILC. By contrast, the ILC is composed of a fairly random selection of international lawyers, many of them with a Foreign Office background (rather than judicial or academic ${ }^{42}$ ). Moreover, it is clear that some states have very little interest in sponsoring an ILC member. The Netherlands, e.g., has provided three members since 1949 (Francois, Tammes and Riphagen), but none since 1986, when

\footnotetext{
${ }^{41}$ Eldar, 'Vote Trading in International Institutions', (2008) 19 European Journal of International Law, 3.

${ }^{42}$ This requires a nuance of course, in that in many countries dividing lines between Foreign Office and the academy are porous. The point though for present purposes is that many of the ILC members may be socialized into partisan thinking, as state representatives.
} 
Riphagen's term ended. A large state such as Indonesia has provided only two (Kusuma-Atmadja and Wisnumurti), as has Sweden (Sandström and Jacobsson), while Belgium has not provided a single ILC member since the ILC started in $1949 .{ }^{43}$ Geographical representation apart, the ILC also does not have a terribly strong record on gender equality. Azaria sketches a compelling picture of the authority exercised by the ILC, but does not get around to the question why the authority of the ILC should be accepted. ${ }^{44}$

Chasapis Tassinis likewise focuses on interpretation, but instead of assigning authority to interpret to a particular body, his focus rests on the role of interpretation with respect to customary international law. He makes the excellent point that interpretation pervades custom in all stages of its existence: one cannot think of custom without interpreting facts, or even without providing an interpretation of which facts are considered relevant to begin with. What is unclear, moreover, is how far his concept of "interpretation" reaches - it might reach farther than is responsible. Clearly, interpretation is meant as a methodological device, in much the same way as the relevant provisions of the Vienna Convention on the Law of Treaties are meant as methodological devices, telling treaty interpreters what to do, although he sensibly remarks that the interpretation cannot be an investigation into authorial intent. ${ }^{45}$ But how far can that analogy be taken? Treaty interpreters are confronted with a written, and more or less (always "more or less") complete text. Interpreters of custom, however, rarely have this luxury, and indeed that is part of the point Chasapis Tassinis makes. They first have to establish whether the thing they claim represents a customary rule does indeed represent such a rule, and this entails not just interpreting a written provision with a beginning and an ending, but also interpreting materials, some of which may not be written, and even interpreting underlying assumptions, which typically are not written to begin with. The process, quite literally, has no beginning and no end, ${ }^{46}$ rendering it extremely vulnerable to manipulation. Calling all of this "interpretation" may not be very helpful, even if it does involve interpretation. But the search for relevant materials involves more than only interpretation. Finally, Kristina Daugirdas makes an argument of a different nature, aiming to demonstrate that international organizations should be recognized as being able to contribute to the formation of customary international law. This complements an earlier article in which she argued that international organizations are bound by customary international law. ${ }^{47}$ Hence, it would seem to

\footnotetext{
${ }^{43}$ For those who are into this sort of thing, Belgium may actually have the last laugh here, in that it provides a disproportionate share of the registrars of the ICJ and other international courts and tribunals - and one might well argue that a tribunal's registrar is far more powerful than a member of the ILC.

${ }^{44}$ She does suggest that authoritative interpretation can be seen as part of the ILC's mandate, but that merely shifts the problem: is the mandate of the ILC, devised over 70 years ago, still credible as a justification for the exercise of authority?

${ }^{45}$ Whether these are successful, or even can be successful, is a different matter: see Klabbers, 'Virtuous Interpretation', in M. Fitzmaurice et al. (eds), Treaty Interpretation and the Vienna Convention on the Law of Treaties: Thirty Years On (2010) 17.

${ }^{46}$ It is in part for this reason that the Vienna Convention is reluctant to promote resort to a treaty's travaux préparatoires: it would provoke all sorts of discussion as to which materials are part of the travaux, and which are not. See further Klabbers, 'International Legal Histories: The Declining Importance of Travaux Préparatoires in Treaty Interpretation?, (2003) 50 Netherlands International Law Review, 267.

47 Daugirdas, 'How and Why International Law Binds International Organizations', (2016) 57 Harvard International Law Journal, 325. For the record, I do not share her position: see Klabbers, 'Sources of International Organizations' Law:
} 
follow that they should also be able to contribute to customary international law, and within the four corners of her article, she does indeed make a persuasive case. There is no prohibition in international law preventing organizations from contributing to customary international law, and doctrines concerning implied and inherent powers can be stretched so as to encompass a power to participate in the formation of customary international law. One caveat, seemingly ignored by Daugirdas, is in order though: in its Namibia opinion, the ICJ rather carefully suggested the possibility of there being a practice of the United Nations relating to voting in the Security Council. The Court avoided using the vocabulary of customary international law, and it might be useful to make a mental note to the effect that the practices of a particular organ are first and foremost practices of that organ. Indeed, more generally (as discussions concerning the formulation of the Articles on Responsibility of International Organizations amply illustrate ${ }^{48}$ ), unlike states, organizations tend be very different from each other, and are supposed to be limited to acting within a given function or set of functions.

What does Daugirdas' position entail? It entails, as Daugirdas suggests, that organizations can help to make custom relating to their own position, most notably perhaps concerning their own privileges and immunities. The relevance hereof should not be exaggerated though: privileges and immunities tend to be negotiated or calibrated on a case-by-case basis, so there is little need for a customary basis and, in reality, not much reliance either. An organization may perhaps claim that on the basis of customary international law, it would be entitled to privileges and immunities; but the precise level of that organization's privileges and immunities remains subject to negotiation. ${ }^{49}$ It will also entail that organizations can contribute to the formation of customary international law if and when they act on a par with states. Daugirdas provides examples relating to the exercise of territorial administration (where arguably practice is too scarce to speak of custom ${ }^{50}$ ); the promulgation of existing norms (again, it is doubtful whether custom is the best label here), and the practice of organizations as treaty depositaries. The latter is no doubt accurate: to the extent that there is customary international law relating to the role and functions of the depositary, it will have been built in part on the practices of the UN, the Council of Europe, and other international organizations.

Perhaps the most significant indirect consequence of organizations' contribution to custom is that "international organizations are certainly bound by the customary international law rules that they help to create." ${ }^{11}$ That may be so, but immediately raises the legitimacy question. Presuming Daugirdas is correct in her conclusion here (as she may well be), the net result is that international

\footnotetext{
Reflections on Accountability', in S. Besson and J. d'Aspremont (eds), The Oxford Handbook on the Sources of International Law (2017) 987.

${ }^{48}$ See e.g. quite a few of the contributions to M. Ragazzi, Responsibility of International Organizations: Essays in Memory of Sir lan Brownlie (2013).

${ }^{49}$ Note also that even rules on privileges and immunities have distributive effects and come with opportunity costs, meaning that local authorities will not always wish to be very generous: any dollar earned but not taxed means less money for public projects, and any illegally parked diplomatic car usurps space for local citizens.

50 There is moreover, again, the potential problem of abstraction: it may well become a customary rule that territorial administration announces to respect specified human rights norms, but that alone says little about which precise norms, and in which precise formulation.

${ }^{51}$ Daugirdas, $\mathrm{ms}$, at 42.
} 
law is (partly) made by entities without any democratic pedigree. That may not be terribly dramatic when it concerns the tasks of treaty depositaries, but becomes already considerably more serious if, as she suggests, international organizations, when exercising territorial administration, may also contribute to human rights law. And this would typically involve strengthening some existing norms, while ignoring or overruling others. ${ }^{52}$ This may not be much of a practical issue when those organizations do morally good work, but that is something that can no longer be taken for granted - and probably never could. ${ }^{53}$ In this connection, it may also be worth noting that organizations, as a general rule, have no standing before international tribunals, and are shielded from scrutiny by domestic courts. Hence, embracing the idea of organizations as making customary international law effectively creates undemocratic law-makers whose acts cannot be reviewed. Surely, few can deem this a desirable state of affairs.

In the end, Daugirdas' argument makes sense only against the background of the epistemic assumption that international organizations are inherently benign, turning the proverbial swords into the equally proverbial plowshares. ${ }^{54}$ For it is only on the basis of such an assumption that lawmaking by unelected and unaccountable entities can be considered pragmatically acceptable, and even then only on the further assumption (topos is perhaps a better label) that the end justifies the means. ${ }^{55}$ Surely though, claiming that the end justifies the means is little more than a consequentialist conceit and, of more immediate concern, the assumption that international organizations are inherently benign, while a popular staple of thinking about international organizations, is no longer plausible. Strongly put, quite a few international organizations are little more than organized lobbies (either for their member states or other constituencies), and even the most "technical" international organizations take decisions that have distributive effects: they benefit some, at the expense of others, and are thus not inherently benign. ${ }^{56}$

\section{To Conclude}

Much is written these days about a crisis in international law, a crisis in global governance, with US President Trump and other authoritarian leaders presented as populists, aiming to undermine international law, aiming to undermine multilateralism, appealing to baser parochial, nationalist sentiments. Accurate as this may be, it sometimes suffers from selection bias and hyperbole ${ }^{57}$ and, more importantly, the proper response cannot be to offer more of the same. International law cannot be saved by adopting a resolution calling upon the world to save international law; it

\footnotetext{
52 Would existing norms, moreover, be allowed to override new practices of the UN, or UNHCR?

53 Indeed, what to make of the work of organizations working broadly in humanitarian settings but without a strong humanitarian mandate, such as the International Organization for Migration? On the latter, see Klabbers, 'Notes on the Ideology of International Organizations Law: The International Organization for Migration, State-making, and the Market for Migration', (2019) 32 Leiden Journal of International Law, 383.

${ }^{54}$ I. Claude, Swords into Plowshares: The Problems and Progress of International Organization, $2^{\text {nd }}$ edn. (1959).

${ }^{55}$ On the role of topoi, see F. Kratochwil, Rules, Norms, and Decisions: On the Conditions of Practical and Legal Reasoning in International Relations and Domestic Affairs (1989).

${ }^{56}$ See, e.g., Klabbers, 'International Organizations and the Problem of Privity: Towards a Supra-Functionalist Approach', in G. Politakis et al. (eds), ILO 100: Law for Social Justice (2019) 629.

${ }^{57}$ Talmon, 'The United States under President Trump: Gravedigger of International Law', (2019) 17 Chinese Journal of International Law, 645.
} 
cannot be saved by a treaty against populism. And neither can it be saved by entrusting interpretation to the ILC, or by allowing international organizations to participate in the making of customary international law, or even by realizing, however accurately, that custom too requires interpretation, and does so at many stages.

To be fair, the contributions by Azaria, Daugirdas and Chasapis Tassinis, blissfully, do not promise the salvation of international law; they know better. They remain content by taking on large questions in relatively small doses, but there is a risk in doing this, and in the preceding pages I have aimed to articulate my unease. That unease is perhaps best summed up by suggesting that work on the boundary of political theory and international law (and things can hardly get closer to that boundary than when talking about law-making and authority) is at its best when sensitive to political theory. I think Azaria is absolutely right in demonstrating that the ILC interprets international law, and even in claiming that "nothing inherent in 'interpretation' restricts the Commission from interpreting." 58 Likewise, Daugirdas demonstrates that international organizations can contribute to some customary international law, while Chasapis Tassinis persuasively posits that custom too generates issues related to interpretation. My problem is not with any of their diagnoses - they are, by and large, compelling. My problem, instead, is with the underlying sentiment that leaving matters to the ILC or to international organizations or to whoever gets to interpret, might be a good thing. For it is this sentiment, pervasive in much doctrinal work on the sources of international law, that straddles the boundary with political theory or political philosophy - that cannot but touch on the pros and cons of various forms of exercising political authority.

The broader point is perhaps best seen as a matter of professional awareness, or the faculty of judgment - Aristotelian phronesis. The academic international lawyer must, obviously, be technically competent, and this Azaria, Chasapis Tassinis and Daugirdas are. But in making technically competent arguments, the academic (there are different considerations relating to the barrister or litigator or government lawyer ${ }^{59}$ ) should ideally also keep an eye out for the assumptions on which their work is based, and the possible ramifications of the arguments that they so ably arrive at. And when writing about the making of international law, such would entail keeping an eye out for issues of democracy and accountability, and making sure that the work is built on solid foundations. In other settings, other sensibilities may enter the picture: the academic human rights lawyer arguing that waterboarding stops just short of constituting torture, or the academic investment lawyer suggesting that entire populations can be driven into starvation because "the law protects investments", ought to demonstrate an awareness that their arguments will affect people of flesh and blood. But when it comes to discussing issues of international law-making, some sensibility for such things as democracy, representation, participation and the like on the part of the academic international lawyer would not be amiss. After all, no matter how technically brilliant our arguments and analyses, at the end of the day the

\footnotetext{
${ }^{58}$ Azaria, manuscript (final) at 10.

${ }^{59}$ See, e.g., D. Luban, Lawyers and Justice: An Ethical Study (1988); A. Kronman, The Lost Lawyer: Failing Ideals of the Legal Profession (1993); B. Wendel, Lawyers and Fidelity to Law (2010).
} 
law is about people of flesh and blood, and it stands to reason to suggest that their fates are not decided on the basis of superbly crafted legal arguments alone. 